\title{
Effects of Public Expenditure On Economic Development In Nigeria
}

\author{
Uket Eko Ewa, Ph.D, FCA \\ Cross River University Of Technology. \\ Cross River State, Nigeria \\ Christopher Ubi Okoi, B.Sc, M.Sc, ACA \\ Office Of The Auditor General Of The State \\ Cross River State, Nigeria
}

\begin{abstract}
This study examined the effect of public expenditure on economic development in Nigeria for the period 2000-2015. Ordinary Least Square (OLS) multiple regression model was employed on the perceived causal relationship between public expenditure and economic development. The study revealed that capital expenditure on Economic Services and recurrent expenditure on administration exerted positive and insignificant effect on unemployment rate in Nigeria while public expenditure on social and community service exerted negative and insignificant effect on unemployment rate in Nigeria. Also the study revealed that capital expenditure on Economic Services and Social and Community Services exerted positive and significant effect on private investment in Nigeria while recurrent expenditure on administration exerted negative and significant effect on private investment in Nigeria. In all, the study revealed a significant impact of public expenditure on GDP, unemployment rate and private investment in Nigeria for the period 2000-2015. It is recommended amongst others that capital and recurrent expenditures on economic services should be directed mainly to the agricultural sector. This will stimulate activities in the economic sectors and, perhaps, reverse the negative effect on economic development.
\end{abstract}

[Keywords]: economic development, gross domestic product, public expenditure. capital, unemployment.

\section{INTRODUCTION}

The recent revival of interest in growth theory has also revived interest among researchers in verifying and understanding the linkages between government expenditure and economic growth. The general view is that public expenditure can be growth-enhancing although the financing of such expenditure can be growth-retarding, due to the negative effects associated with taxation and excessive debt. Over the past decades, public sector spending in Nigeria has been increasing through government various activities.

The size and structure of public expenditure determine the pattern and form of growth in output of the economy. Nigeria's public expenditure is dominated by recurrent expenditure, though statistics have shown that the growth rate of the nation's economy had been impressive in recent times. As development is anchored on capital expenditure, this goes to show that the country has been experiencing growth without development. It also shows that a large percentage of Nigeria's population does not benefit from the expenditure of her government. Thus the intended objectives and goals of government expenditure have been largely defeated. 


\section{Statement of the Problem}

In Nigeria, government expenditure has continued to rise due to increased demand for public goods like roads, communication, power, education, health and increasing need to provide both internal and external security. Unfortunately, rising government expenditure has not translated to meaningful growth and development as Nigeria ranks among the poorest countries in the world with more than 50 percent living on less than US\$2 per day. Also dilapidated infrastructure (especially roads and power supply) abound and has led to the collapse of many industries and high level of unemployment. Moreover, macroeconomic indicators like balance of payments, import obligations, inflation rate, exchange rate, and national savings points to Nigeria not faring well over the years.

It is against this background that this study is carried out to empirically investigate the effects of Nigeria's public expenditure on economic development.

\section{Objectives of the study}

i. To determine the relationship between public expenditure and Gross Domestic Product (GDP) in Nigeria.

ii. To examine the relationship between public expenditure and unemployment in Nigeria.

iii. To evaluate the effects of public expenditure on private investment in Nigeria.

\section{The Public Expenditure Theory:}

\section{THEORETICAL FRAMEWORK}

To give direction to the empirical investigation, this study was built on the foundation of public expenditure theory. This theory traditionally, received only a scanty attention till recently. This lop-sided interest in the theory of public finance is explained by a general acceptance of the philosophy of laissez-faire and belief in the efficacy of free market mechanism. However, with the advent of welfare economics the role of the state has expanded especially in the area of infrastructural provision and theory of public expenditure is attracting increasing attention. This tendency has been reinforced by the widening interest of economists in the problems of economic growth, planning, regional disparities, distributive justice and the like (Bhatia, 2002).

\section{Peacock and Wiseman's theory of expenditure.}

Peacock and Wiseman's study is probably one of the best known analyses of the time pattern of public expenditures. They founded their analyses upon a political theory of public determination namely that governments like to spend more money and citizens do not like to pay taxes, and that government need to pay some attention to the wishes of their citizens. The duo saw taxation as setting a constraint on government expenditure. As the economy and thus incomes grew, tax revenue at constant tax rate would rise, thereby enabling public expenditure to show a gradual upward trend even though within the economy there might be a divergence between what people regarded as being desirable level of public expenditure and the desirable level of taxation.

\section{Ernest Engel's theory of public expenditure}

Engel pointed out over a century ago that the composition of the consumer budget changes as family income increases. A smaller share comes to be spent on certain goods such as work clothing and a larger share on others, such as for coats, expensive jewelries etc. As average income increase, smaller changes in the consumption pattern for the economy may occur.

\section{Concept of public expenditure}

Public expenditure refers to government expenditure which is incurred by either federal, state or local Governments, (http://kalyan-city.blogspot.com.ng/2011/02/what-is-public- 
expenditure-meaning-and.html.). This expenditure is incurred on various activities for the common good or welfare of the people and also for the economic development, especially in developing countries. Until the 19th century, public expenditure was limited as laissez faire philosophies believed that money left in private hands could bring better returns. However, in the 20th century, Keynes argued for the role of public expenditure in determining levels of income and distribution in the economy. Since then government expenditures has shown an increasing trend https://en.wikipedia.org/wiki/Public_expenditure).

\section{Concept of economic development}

Perhaps the only agreement currently is that economic development is difficult to define. Nevertheless defining economic development is a necessary prerequisite to move discussion towards objective policy discussion and robust measurement. The first step in defining economic development is distinguishing it from the concept of economic growth. Economic growth has a strong theoretical grounding and is easily quantified as an increase in aggregate output. It is the capacity of a national economy to generate and sustain an annual increase in its GDP. It involves the planned alteration of the structure of production and employment so that agriculture's share of both declines and that of manufacturing and service industries increase. Economic development is also a multidimensional process involving major changes in social structures, popular attitudes and national institutions as well as the acceleration of economic growth, the reduction of inequality and eradication of poverty. It is more concerned with enhancing the lives people leave and the freedom they enjoy. Economic development is measured by rising real per capita income, Gini coefficients and other measures of the distribution of income and wealth as well as indicators of quality of life, that range from life expectancy, crime statistics to environmental quality (source). From this standpoint, economic development differs from growth in terms of focus on a broader set of metrics.

Economic development is also a professional practice that uses definitions more inclusively than those of academic economists. Two influential American planners, Fitzgerald and Leigh (2002) propose that, "economic development preserves and raises the community's standard of living through a process of human and physical infrastructure development based on principles of equity and sustainability." This adds to the concept of community and expands the objectives of economic development to explicitly embrace equity and also highlights sustainability. In this conceptualization, economic development is about creating choice or expanding the opportunity set for both consumers and businesses.

\section{Empirical review of public expenditure in Nigeria}

In Nigeria, many studies have attempted to investigate the relationship between government expenditure and economic growth, and the impact thereof. Akpan (2005) used a disaggregated approach to examine the relationship using components capital, recurrent, administrative, economic service, social and community service, and transfers expenditures and the study found no significant relationship between economic growth and most components of government expenditure in Nigeria.

Suleiman and Aruwa (2009) empirically examined the relationship between government revenues and expenditures, expenditures and economic growth as a fundamental step in understanding the behaviour of Nigerian public expenditure and the economy. His study found support for Wagner's law of ever increasing public finance and Friedman's Hypothesis. The study showed that growth in real GDP was significant before the mid-1990s but thereafter fell below average government revenue and expenditure. He concluded that, during the period 
1978-2008, government expenditure was not employed as a fiscal instrument and that revenue growth drove the government expenditure.

This study improved on some of the existing studies, especially that of Akpan (2005) in that it investigated the partial and joint effects of government expenditure on economic growth in Nigeria using certain disaggregated components of government expenditure. It also updated these studies in terms of currency and detailed analysis, and contributes to the existing literature on the long run relationship between government expenditure and economic growth in Nigeria.

As expenditure on infrastructure such as roads, communications, power, etc, reduces production costs, increases private sector investment and profitability of firms, thus fostering economic growth, Al-Yousif (2000); Abdullah (2000) Ranjan and Sharma (2008); and Cooray (2009) in their support concluded that expansion of government expenditure contributes positively to economic growth. However, some scholars did not support the claim that increasing government expenditure promotes economic growth, instead they assert that higher government expenditure may slowdown overall performance of the economy as attempt to finance rising expenditure, government may increase taxes and/or borrowing.

In the assertion of bid to score cheap popularity by politicians in power and ensure that they continue to remain in power, politicians and governments officials sometimes increase expenditure and investment in unproductive projects or in goods that the private sector can produce more efficiently and thus misallocation of resources and impeding the growth of national output, studies by Folster and Henrekson (2001), suggested that large government expenditure has negative impact on economic growth.

\section{METHODOLOGY}

Building on the existing theoretical and empirical literature, this study perceived a causal relationship between government expenditure and economic development. Therefore, exploratory causal study design was used to investigate the impact of government expenditure on economic development within the context of Nigerian economy. This design was adopted because the data used has already been processed by the Central Bank of Nigeria (Statistical Bulletin) and did not require the generation of primary data.

The population of the study consisted of the 536 Ministries, Departments and Agencies (MDAs) of the federal government of Nigeria, an unspecified number of Ministries, Departments and Agencies, (MDAs) of the 36 states and the Federal Capital Territory as well as the 774 local government councils of Nigeria.

\section{Sample Procedure and Sample Size Determination}

A non-probability technique was used for this study. Specifically the study adopted the convenience sampling techniques and restricted the research to the 536 Ministries, Departments and Agencies (MDAs) of the federal government for a 16-year period from year 2000-2015. The choice of this convenient sampling technique was due to the availability of secondary data on this tier of government.

\section{Model Specification}

Based on the perceived causal relationship between the identified variables of the research, a Multiple Regression model which is stochastic in nature was specified to link government expenditure and economic development. Estimation of the model was by ordinary least squares (OLS) techniques facilitated by the application of Statistical Package for Social Science 
(SPSS). Variables used for the model were Gross Domestic Product (GDP), Unemployment rate, and Private Investment in Nigeria as dependent variables while public expenditures on Administration (PEA), on Economic services (PEES) and on Social and Community Services (PESCS) were explanatory variables. Thus, the models were linearly expressed as follows:

Where:

$$
\mathrm{GDP}=\mathrm{b}_{0}+\mathrm{b}_{1} \text { PEA }+\mathrm{b}_{2} \text { PEES }+\mathrm{b}_{3} \text { PESCS }+\mu
$$

$\mathrm{GDP}=$ Gross Domestic Product in Nigeria.

PEA = Public expenditure on administration.

PEES = Public expenditures on economic services.

PESCS $=$ Public expenditure on social and community services

$$
\text { Unempl }=\mathrm{b}_{0}+\mathrm{b}_{1} \text { PEA }+\mathrm{b}_{2} \text { PEES }+\mathrm{b}_{3} \text { PESCS }+\mathrm{e} .
$$

Where:

Unempl= Unemployment rate in Nigeria.

PEA = Public expenditure on administration.

PEES = Recurrent expenditures on economic services.

PESCS = Public expenditure on social and community service.

$$
P R I=b_{0}+b_{1} \text { PEA }+b_{2} \text { PEES }+b_{3} \text { PESCS }+a
$$

Where:

PRI= Private investment in Nigeria.

PEA = Public expenditure on administration.

PEES = Public expenditures on economic services.

PESCS = Public expenditure on social and community service.

$\mathrm{b}_{0}=$ Intercept of the regression line.

bi $(i=1,2,3)$ are coefficients or weights of the components of public expenditure. $\mu, \mathrm{e}, \mathrm{a}$, are stochastic variables 
Table 1: Macro-economic variables to measure the effects of public expenditure on gross domestic product in Nigeria

\begin{tabular}{|c|c|c|c|c|}
\hline Years & $\begin{array}{l}\text { Real } \\
\text { (Billions) }\end{array}$ & PEA (Billions) & $\begin{array}{l}\text { PEES } \\
\text { (Billion) }\end{array}$ & $\begin{array}{l}\text { PEESCS } \\
\text { (Billions) }\end{array}$ \\
\hline 2000 & $23,688.28$ & 197.81 & 140.10 & 112.75 \\
\hline 2001 & $25,267.54$ & 230.05 & 312.77 & 132.97 \\
\hline 2002 & $28,951.71$ & 340.09 & 268.28 & 184.01 \\
\hline 2003 & $31,709.45$ & 395.93 & 194.05 & 158. 01 \\
\hline 2004 & $35,020.55$ & 444.54 & 226.50 & 164.42 \\
\hline 2005 & $37,474.95$ & 606.24 & 329.34 & 223.01 \\
\hline 2006 & $39,995.50$ & 707.42 & 341.90 & 272.85 \\
\hline 2007 & $42,922.41$ & 853.33 & 537.45 & 407.57 \\
\hline 2008 & $46,012.52$ & $1,018.08$ & 818.04 & 485.10 \\
\hline 2009 & $49,856.10$ & $1,006.08$ & 929.62 & 499.12 \\
\hline 2010 & $54,612.26$ & $1,377.60$ & 974.95 & 702.67 \\
\hline 2011 & $57,511.04$ & $1,494.20$ & 696.90 & 878.29 \\
\hline 2012 & $59,929.89$ & $1,349.90$ & 551.14 & 887.46 \\
\hline 2013 & $63,218.72$ & $1,395.47$ & 797.00 & 998.78 \\
\hline 2014 & $67,152.79$ & $1,222.47$ & 659.85 & 886.06 \\
\hline 2015 & $69,023.93$ & $1,455.80$ & 624.11 & 890.60 \\
\hline
\end{tabular}

Source: CBN Statistical Bulletin, (2016), World Development Indicator (2016)

Table 2

Macroeconomic variables to measure the effects of Public expenditure on unemployment rate

\begin{tabular}{|c|c|c|c|c|}
\hline YEARS & $\begin{array}{l}\text { UNEMPLOYMENT } \\
\text { RATE \% }\end{array}$ & $\begin{array}{l}\text { PEA } \\
\text { (BILLION) }\end{array}$ & $\begin{array}{l}\text { PEES } \\
\text { (BILLION) }\end{array}$ & $\begin{array}{r}\text { PEESCS } \\
\text { (Billions) }\end{array}$ \\
\hline 2000 & 13.1 & 197.81 & 140.10 & 112.75 \\
\hline 2001 & 13.6 & 230.05 & 312.77 & 132.97 \\
\hline 2002 & 12.6 & 340.09 & 268.28 & 184.01 \\
\hline 2003 & 14.8 & 395.93 & 194.05 & 158. 01 \\
\hline 2004 & 13.4 & 444.54 & 226.50 & 164.42 \\
\hline 2005 & 11.9 & 606.24 & 329.34 & 223.01 \\
\hline 2006 & 12.3 & 707.42 & 341.90 & 272.85 \\
\hline 2007 & 12.7 & 853.33 & 537.45 & 407.57 \\
\hline 2008 & 14.9 & $1,018.08$ & 818.04 & 485.10 \\
\hline 2009 & 19.7 & $1,006.08$ & 929.62 & 499.12 \\
\hline 2010 & 21.1 & $1,377.60$ & 974.95 & 702.67 \\
\hline 2011 & 23.9 & $1,494.20$ & 696.90 & 878.29 \\
\hline 2012 & 21.1 & $1,349.90$ & 551.14 & 887.46 \\
\hline 2013 & 10.6 & $1,395.47$ & 797.00 & 998.78 \\
\hline 2014 & 9.7 & $1,222.47$ & 659.85 & 886.06 \\
\hline 2015 & 9.9 & $1,455.80$ & 624.11 & 890.60 \\
\hline
\end{tabular}

Source: CBN Statistical Bulletin, (2016), World Development Indicator (2016) 
Table 3

Least square regression result of effects of public expenditure on unemployment rate and private investment in Nigeria

Gross Domestic Product,

unemployment and

Private Investment in

Nigeria for the period

R R Square Adjusted Std. Error of

R Square the Estimate

$\mathrm{F}$

(Model Summary)

$\begin{array}{lllrrr}\text { GDP } & .972^{\mathrm{a}} & 0.945 & 0.931 & 3920.34375 & 68.658 \\ \text { Unemployment } & .538^{\mathrm{a}} & 0.289 & 0.112 & 4.1004 & 1.629\end{array}$

Private Investment

$.714^{\mathrm{a}}$

0.51

0.388

544248.9004

4.17

a. Predictors: (Constant), PESCS, PEES, PEA

Source: SPSS Analysis

Table 4

Least square regression result of effects of public expenditure on Gross Domestic Product in Nigeria for the period (ANOVA)

\begin{tabular}{lccccc}
\hline Model & Sum of Squares & Df & Mean Square & F & Sig \\
\hline Regression & 3165612023 & 3 & 1055204008 & 68.658 & $.000^{\mathrm{b}}$ \\
Residual & 184429141.8 & 12 & 15369095.2 & & \\
Total & 3350041165 & 15 & & & \\
\hline
\end{tabular}

Table 5

Least square regression result of effects of public expenditure on Gross Domestic Product in Nigeria for the period (Regression coefficients)

\begin{tabular}{lccccc}
\hline Model & Unstandardized Coefficients & $\begin{array}{c}\text { Standardized } \\
\text { Coefficient } \\
\text { Beta }\end{array}$ & $\mathrm{T}$ & Sig \\
& $\mathrm{B}$ & Std Error & & & \\
\hline 1 & & & & & \\
(constant) & 21269.684 & 2466.141 & & & \\
PEA & 19.154 & 9.635 & 0.688 & 1.988 & 0.07 \\
PEES & 3.886 & 5.097 & 0.071 & 0.762 & 0.461 \\
PESCS & 9.872 & 13.153 & 0.242 & 0.751 & 0.467 \\
\hline
\end{tabular}


Table 6

Macroeconomic variables used to measure the effects of Public expenditure on Private investment in Nigeria.

\begin{tabular}{lllll}
\hline YEARS & PRI (BILLION) & $\begin{array}{l}\text { PEA } \\
\text { (BILLION) }\end{array}$ & $\begin{array}{l}\text { PEES } \\
\text { (BILLION) }\end{array}$ & $\begin{array}{c}\text { PEESCS } \\
\text { (Billions) }\end{array}$ \\
\hline 2000 & $163,963.90$ & 197.81 & 140.10 & 112.75 \\
2001 & $216,258.10$ & 230.05 & 312.77 & 132.97 \\
2002 & $242,786.50$ & 340.09 & 268.28 & 184.01 \\
2003 & $311,190.30$ & 395.93 & 194.05 & 158.01 \\
2004 & $358,716.80$ & 444.54 & 226.50 & 164.42 \\
2005 & $400,388.80$ & 606.24 & 329.34 & 223.01 \\
2006 & $586,213.50$ & 707.42 & 341.90 & 272.85 \\
2007 & $748,246.80$ & 853.33 & 537.45 & 407.57 \\
2008 & $108,383.80$ & $1,018.08$ & 818.04 & 485.10 \\
2009 & $1,165,579.60$ & $1,006.08$ & 929.62 & 499.12 \\
2010 & $1,587,098.50$ & $1,377.60$ & 974.95 & 702.67 \\
2011 & $1,859,569.40$ & $1,494.20$ & 696.90 & 878.29 \\
2012 & $2,016,071.50$ & $1,349.90$ & 551.14 & 887.46 \\
2013 & $1,781,909.50$ & $1,395.47$ & 797.00 & 998.78 \\
2014 & $64,160.15$ & $1,222.47$ & 659.85 & 886.06 \\
2015 & $9,994.66$ & $1,455.80$ & 624.11 & 890.60 \\
\hline
\end{tabular}

Source: CBN Statistical Bulletin, (2016), World Development Indicator (2016)

Table 7

Least square regression result of effects of public expenditure on Unemployment rate in Nigeria for the period (ANOVA)

\begin{tabular}{lccccc}
\hline Model & $\begin{array}{c}\text { Sum of } \\
\text { Squares }\end{array}$ & Df & $\begin{array}{c}\text { Mean } \\
\text { Square }\end{array}$ & F & Sig \\
\hline 1 & & & & & \\
Regression & 82.172 & 3 & 27.391 & 1.629 & $.235^{\mathrm{b}}$ \\
Residual & 201.758 & 12 & 16.813 & & \\
Total & 283.929 & 15 & & & \\
\hline
\end{tabular}

Table 8

Least square regression result of effects of public expenditure on Unemployment rate in Nigeria for the period (Regression coefficients)

\begin{tabular}{|c|c|c|c|c|c|c|}
\hline \multirow[t]{2}{*}{ Model } & \multirow[b]{2}{*}{ B } & \multicolumn{2}{|c|}{$\begin{array}{l}\text { Unstandardized } \\
\text { Coefficients }\end{array}$} & \multirow[t]{2}{*}{$\begin{array}{l}\text { Standardized } \\
\text { Coefficient } \\
\text { Beta }\end{array}$} & \multirow[t]{2}{*}{$\mathrm{t}$} & \multirow[t]{2}{*}{ Sig } \\
\hline & & & Std Error & & & \\
\hline $\begin{array}{l}1 \\
\text { (constant) }\end{array}$ & & 10.406 & 2.579 & & 4.034 & 0.002 \\
\hline PEA & & 0.006 & 0.01 & 0.687 & 0.553 & 0.59 \\
\hline PEES & & 0.008 & 0.005 & 0.527 & 1.571 & 0.142 \\
\hline PESCS & & -0.01 & 0.014 & -0.839 & -0.723 & 0.483 \\
\hline
\end{tabular}


Table 9

Least square regression result of effects of public expenditure on Private investment in Nigeria for the period (ANOVA)

\begin{tabular}{lccccc}
\hline Model & $\begin{array}{c}\text { Sum of } \\
\text { Squares }\end{array}$ & Df & $\begin{array}{c}\text { Mean } \\
\text { Square }\end{array}$ & F & Sig \\
\hline Regression & $3.71 \mathrm{E}+12$ & 3 & $1.24 \mathrm{E}+12$ & 4.17 & $.031^{\mathrm{b}}$ \\
& & & & & \\
$\begin{array}{l}\text { Residual } \\
\text { Total }\end{array}$ & $3.55 \mathrm{E}+12$ & 12 & $2.96 \mathrm{E}+11$ & & \\
\hline
\end{tabular}

Table 10

Least square regression result of effects of public expenditure on private investment in Nigeria for the period (Regression coefficients)

\begin{tabular}{lccccc}
\hline \multicolumn{7}{c}{ Unstandardized Coefficients } & $\begin{array}{c}\text { Standardized } \\
\text { Coefficient } \\
\text { Beta }\end{array}$ & $\mathrm{T}$ & Sig \\
& $\mathrm{B}$ & Std Error & & & \\
\hline 1 & & & & -0.129 & 0.9 \\
(constant) & -44133.373 & 342366.535 & & & \\
PEA & -647.925 & 1337.547 & -0.5 & -0.484 & 0.637 \\
PEES & 1842.178 & 707.583 & 0.726 & 2.603 & 0.023 \\
PESCS & 995.582 & 1825.978 & 0.525 & 0.525 & 0.596 \\
\hline
\end{tabular}

\section{Analysis of Results}

\section{RESULTS AND DISCUSSION}

The study adopted on Table 1 the least square multiple regression model with Public Expenditure on Administration (PEA), Public Expenditure on Economic Service (PEES) and Public Expenditure on Social and Community Service (PESCS) as independent variables used as predictors/indicators of public expenditure in Nigeria and dependent variable as Gross Domestic Product (GDP) for the period 2000-2015.

Table 5 shows the multiple regression equation RGDP $=21269.684+19.154$ PEA+3.886 PEES + 9.872 PESCS. The $b_{0}(21269.684)$ represent the intercept along the ' $Y$ 'axis and indicates the positive change $(=\mathrm{N}=21269.684)$ that could take place in the country's Real Gross Domestic Product (RGDP) if the independent variables (PEA, PEES and PESCS) were held constant.

The public expenditure on Administration (PEA) has a positive relationship with the country's real GDP for the period 2000-2015 with $b_{1}$ (19.15) represents the coefficient measuring Public Expenditure on Administration (PEA). Thus expenditure on administration accounted for $=\mathrm{N}=19.15$ billion increase in the country's GDP. The Public Expenditure on Economic Service (PEES) for the same period has a positive relationship with the country's GDP with $b_{2}(3.87)$ as the coefficient indicating public expenditure on economic services accounted for $=\mathrm{N}=3.87$ billion increase in the country's Gross Domestic product. Also, Public Expenditure on Social and Community Services (PESCS) indicated a positive relationship with the country's GDP for the period 2000-2015 having a coefficient of $b_{3}(9.87)$ indicating that a percentage increase in public expenditure on social and community services accounted for $=\mathrm{N}=9.87$ billion increase in the country's GDP. The correlation coefficient using Pearson moment correlation coefficient 
(R) as stated in Table 3 is 0.972 ie 97 percent, indicating a very strong relationship between the dependent and independent variables used in this study. The coefficient of determination was $\left(\mathrm{R}^{2}\right)$ is 0.945 (95 percent) indicating that the increase in the Gross Domestic Product is a combined effect of the Public Expenditure on Administration, Economic Service and Social and Community Services (PEA, PEES PESCS). Hence, for the period under study (PEA, PEES PESCS) explained 95 percent of the 100 percent variation (increases) that occurred in the dependent variable (RGDP). The remaining percent ( 5 percent) represented the unexplained percentage and could be due to other independent variables not built in the regression model.

The study as stated in Table 7 adopted the least square multiple regression model to measure the impact of Public expenditure on Administration, Public expenditure on Economic Services, Social and Community Services used as predictors/indicators of expenditure on Unemployment Rate (dependent variable) for the period 2000-2015. Table 8 shows the multiple regression equation $-\mathrm{UNEMPL}=10.406+0.006$ PEA $+0.008 \mathrm{PEES}-0.010 \mathrm{PESCS}$ where $\mathrm{b}_{\mathrm{o}}(10.406)$ represent the ' $\mathrm{Y}$ ' intercept which indicates changes that could take place in the Country's unemployment rate if the independent variables (PEA, PEES and PESCS) were held constant. The $b_{1}(0.006)$ coefficient of public expenditure on administration (PEA indicates that a percentage increase in public expenditure on administration accounted for less than one percent increase in unemployment rate in the Country. The coefficient shows that Public expenditure on administration has a marginal positive relationship with the unemployment rate. Also public expenditure on economic services has a positive relationship though minimal with the country's unemployment rate. This result is contrary to a priori expectation because public expenditure on economic services creates employment and therefore should significantly reduce unemployment rate. The coefficient $b_{2}(0.008)$ is less than one indicating a very weak relationship between public expenditure on economic services and unemployment rate. The positive relationship could be attributed to the existence of natural unemployment rate which is theoretically accepted to be up to 4 percent under full employment scenario due to frictional factors.

Public expenditure on social and community services has a negative relationship with the Country's unemployment rate for the period 2000-2015. The $b_{3}(-0.010)$ indicated that a percentage increase in public expenditure on social and community services for the period accounted for less than one percent decrease in unemployment rate in the Country. This result is consistent with a priori expectation because public expenditure on social and community services which includes expenditure on education, health, sports and recreation enhances the productivity of beneficiaries and boosts employment thereby reducing the unemployment rate of the Country. The correlation coefficient using Pearson Moment Correlation Coefficient (R) as indicated in Table 3 was 0.538 (54 percent) indicating a strong relationship between the unemployment rate (dependent) and PEA, PEES and PESCS (independent variables) used in this study. The coefficient of determination $\left(\mathrm{R}^{2}\right)$ of 0.289 (29 percent) indicates that the independent variables (PEA, PEES and PESCS) accounted for 29 percent of the total variation (100 percent) in the dependent variable (unemployment rate) for the period of the study. The remaining 71 percent represent the unexplained percentage due to other independent variables not built in the regression model.

The model on regressing public expenditure on administration (PEA), economic services (PEES) and social and community services (PESCS) used as predictors/indicators on the dependent variable-private Investment (PRI) in Nigeria for the period 2000-2015 as presented in Table 10. The Table showed multiple regression equation as:

$\mathrm{PRI}=-44133.373-647.925 \mathrm{PEA}+1842.176 \mathrm{PEES}+995.582 \mathrm{PESCS}$ 
where $b_{o}(-44133.373)$ represent the ' $Y$ ' intercept which indicated a negative change in private investment in Nigeria when the independent variables (PEA,PEES and PESCS) were held constant. The public expenditure on administration showed a negative relationship with private investment in Nigeria for the period 2000-2015. The $b_{1}(-647.925)$ is the coefficient of public expenditure on administration (PEA). It showed that a percentage increase in public expenditure on administration accounted for $=\mathrm{N}=647.91 \mathrm{~b}$ decrease in private investment in Nigeria which is consistent with a priori expectation as public expenditure on administration does not generate private investment theoretically. Practically, public expenditure on internal and external security infrastructure such as arms and ammunitions, manpower training and development as well as research and development enhance private investment in any country. Public expenditure on economic services has a positive relationship with public investment. The $b_{2}(1842.178)$ is the coefficient of public expenditure on economic services. It showed that a percentage increase in public expenditure on economic services (PEES) accounted for $=\mathrm{N}=1842.18 \mathrm{~b}$ increase in Private Investment in Nigeria for the period of Study. Public expenditure on social and community services (PESCS) has a positive relationship with private investment in Nigeria for the period 2000-2015. The $b_{3}(995.582)$ is the coefficient of public expenditure on social and community services (PESCS).

It showed that a percentage increase in public expenditure on social and community services accounted for $=\mathrm{N}=995.58 \mathrm{~b}$ increase in private investment in Nigeria for the period of study. Both coefficients of public expenditure on economic services (PEES) and social and community services (PESCS) are consistent with apriori expectation. The correlation coefficient using Pearson Moment Correlation Coefficient (R) as shown in Table 3 as 0.714 indicates a very strong relationship between the dependent and independent variables adopted for this study. The coefficient of determination $\left(\mathrm{R}^{2}\right)$ was 0.0510 (51 percent). It indicated that the independent variables/public expenditure on administration, economic services and social and community services (PEA, PEES and PESCS) accounted for 51 percent of the total (100 percent) in the dependent variable: Nigeria's Private Investment.

The remaining 49 percent represent the unexplained percentage which could be due to other independent variables not built in the regression model.

\section{Hypothesis One:}

$\mathbf{H}_{\mathbf{o}}$ : There is no significant relationship between public expenditure and Gross Domestic Product (GDP)

In Table 5, the t-statistic was used to test for the significant relationship of each independent variable. At 5\% level of significance, the theoretical value of $t$ obtained from the $t$ table was 3.06. The calculated t-value for public expenditure on administration (PEA) stood at 1.988 which was less than the theoretical value hence, the null hypothesis was accepted, i.e. there was no significant relationship between public expenditure on administration and Gross Domestic Product for the period between 2000-2015. This is consistent with theoretical apriori postulation which explains that public expenditure on administration will not generate output or growth. The calculated t-value for public expenditure on economic services (PEES) also stood at 0.762 . This is less than the theoretical $t$-value which was 3.06 (i.e. $t-0.762<t 3.06$ ). The null hypothesis is thus accepted which indicated no significant relationship between Public Expenditure on Economic Services and Gross Domestic Product. This is not consistent with theoretical apriori postulations because public expenditure on economic services like agriculture, manufacturing, physical infrastructure, telecommunication etc generate output of goods and services. Similarly the calculated t-value for the Public Expenditure on Social and Community Services (PESCS) stood at 0.751 and it was less than the theoretical t-value which 
was 3.06 and therefore the null hypothesis which states that there was no significant relationship between public expenditure on social and community services and gross domestic product was accepted. This is not consistent with the theoretical apriori position because public expenditure on social and community services such as education, heath, sports and recreation enables beneficiaries of such services to be skillful, well and fit for productive ventures.

From the F-distribution table, with 5 percent level of significance $(3: 15)$ was equal to 3.4 . This was compared with the calculated f-ratio of the three hypotheses. The f-ratio calculated was 68.66 which is greater than the table value of 3.4. Hence, the null hypothesis is rejected while the alternative hypothesis that there was a significant relationship between public expenditure on administration and real gross domestic product in Nigeria for the period 2000-2015 was accepted.

\section{Hypothesis Two}

Ho: No significant relationship exists between public expenditure and unemployment rate in Nigeria.

In Table 8 the t-calculated value for public expenditure in administration (PEA) is 0.553 and it is less than the table value of 3.06. The value portrays a no significant relationship between public expenditure on administration and the unemployment rate in Nigeria for the period 2000-2015. This is not consistent with theoretical apriori expectation that public expenditure on administration does not create employment and hence should increase unemployment rate significantly.

Also the t-calculated value for public expenditure on economic services in Table 8 stood at 1.571 which is less than the table value of 3.06 and thus the null hypothesis that there is no significant relationship existing between public expenditure on economic services and unemployment rate in Nigeria for the period of study is upheld. The calculated t-value for public expenditure on social and community services (PESCS) of 0.723 as recorded in Table 7 is less than the table t-value of 3.06 signifying a no significant relationship between public expenditure on social and community services (PESCS) and unemployment rate in Nigeria for the period of study 2000-2015.

In addition to the t-statistic results above, the result of the F-calculated ratio stood at 1.629 which is lower value than the table value of 3.4 signifying no significant relationship existing between public expenditure on social and community services and unemployment rate in Nigeria for the period 2000-2015.

\section{Hypothesis Three}

Ho: A significant relationship does not exists between public expenditure and private investment in Nigeria

In Table 10, the t-calculated value for public expenditure on administration (PEA) of 0.484 is less than the table value of 3.06 indicating a significant relationship not existing between public expenditure on administration and private investment in Nigeria for the period 20002015. Also in Table 10, the t-calculated value for public expenditure on economic services (PEES) of 2.60 which is less than the table value of 3.06 indicates no significant relationship between public expenditure on economic services (PEES) and private investment in Nigeria for the period 2000-2015. This is not consistent with apriori expectation because public expenditure on economic services increases incomes which should increase savings and 
ultimately increase private investment. The calculated $t$-value for public expenditure on social and community services (PESCS) in Table 10 of 0.545 is less than the table value of 3.06 indicating a significant relationship does not exist between public expenditure on social and community services (PESCS) and private Investment in Nigeria for the period 2000-2015.

In addition to the t-statistics result above, Table 9 shows the result of the calculated $\mathrm{F}$ value of 4.170 which is higher than table value of 3.4 indicating that a significant relationship does exist between public expenditure and private investment in Nigeria for the period of study 20002015.

\section{DISCUSSION OF FINDINGS}

Findings revealed that the ' $Y$ ' intercepts (bo) for two regressions (GDP and unemployment rate on public expenditure) were positive suggesting that in the absence of government intervention in economic activities via the injection of funds, the economy experienced a positive growth. The ' $\mathrm{Y}$ ' intercept (bo) of the regression of Private Investment on Public expenditure was negative implying a decline in economic growth in the absence of government's injection of funds into the economy.

The results further showed that the signs of the coefficients of public expenditure on economic services and social and community services PEES and PESCS respectively were consistent with theoretical expectations of the relationship between public expenditure on economic services and social and community services on real GDP. That of public expenditure on administration is however inconsistent. This implied that while government expenditure on economic services and social and Community services positively affect gross domestic product as expected, public expenditure on administration unexpectedly has a positive relationship with and thus exerted a positive effect on gross domestic product too. The aggregated effect of public expenditure on economic growth is statistically significant. This result supported the Keynesian (1936) view of government's active intervention in the economy using public policy instruments.

The positive coefficients of public expenditure on administration and economic services (PEA and PEES) implied that government expenditure on administration and economic services increased unemployment rate in Nigeria. However, the negative coefficient of public expenditure on social and community services implied that government expenditure on social and community services actually reduces unemployment rate. Notwithstanding, the joint effect of these components of government expenditure on unemployment rate is statistically insignificant and in agreement with Akpan's (2005) submission of no significant relationship existing between economic growth and most components of government expenditure.

Hypothesis three results showed a negative coefficient of public expenditure on administration (PEA) implying a decline in private investment due to increasing expenditure on administration (PEA). The coefficients of public expenditure on economic services and social and community services (PEES and PESCS) were however positive. These implied that private investment increased as public expenditure on economic services (PEES) and social and community services (PESCS) also increased. These results were all consistent with apriori economic theory. Equally, the joint effect of these public expenditure components on private investment in Nigeria is statistically significant as indicated by the computed F-Statistic.

\section{CONCLUSION}

As there is a significant impact of public expenditure on real Gross Domestic Product (GDP), unemployment rate and private investment in Nigeria for the period 2000-2015, it can be said that the higher the government spending, the higher the expected level of economic 
development in Nigeria (ceteris paribus) and the lower the government spending, the lower the expected level of economic development of the country (Nigeria). However, the study revealed that some components of government expenditure exerted negative effect on the components of developments (real GDP, unemployment rate and private investment). That is, public expenditure on social and community service exerted negative effect on unemployment rate and public expenditure on administration exerted negative effect on private investment in Nigeria. The study thus revealed that the decreased Gross Domestic Product, unemployment rate and private investment occasioned by public expenditure is attributable to inefficiency and fiscal indiscipline in public expenditure. Fiscal indiscipline here is manifested in waste, white elephant projects, uncompleted and abandoned projects, policy inconsistency etc. So, it can therefore be said it is because of the level of this corruption in the system that led to the decrease in GDP, unemployment rate and private investment in the period even when the components of the government expenditure (public expenditure on economic and community service and capital expenditure on administration ) were increased.

\section{RECOMMENDATIONS}

Based on the findings and conclusion of this study, we recommend that:

i. Capital and recurrent expenditures on economic services should be directed mainly at the agricultural sector so as to stimulate activities in the economic sectors and, perhaps, reverse the negative effect on economic development.

ii. Nigerian government should promote efficiency in the allocation of development resources through emphasis on private sector participation and privatization or commercialization.

iii. The proportion of government total expenditure that goes into capital and recurrent expenditure financing should be increased since these components exert significant positive effect on GDP.

iv. Since the analysis showed that capital expenditure on social and community services have more positive effect on private investment than the other components, they require more favourable attention in the allocation of government expenditures.

v. Enforce monitoring and evaluation of public expenditure to ensure that released funds are not misused which will engender effectiveness.

\section{References}

Abdullah, H. A, (2000). The relationship between government expenditure and economic growth in Saudi Arabia. Journal of Administrative Science, 12(2), 173-191.

Akpan, N. I. (2005). Government expenditure and economic growth in Nigeria, A disaggregated approach. Central Bank of Nigeria Financial Review, 43(1), 22-34.

Al-Yousif, Y. (2000). Does government expenditure inhibit or promote economic growth: Some empirical evidence from Saudi Arabia. Indian Economic Journal, 48(2). 32-45.

Bhatia, H. L. (2002), Public Finance. 25th ed. Delphi: Vikas Publishing House, PVT Ltd. India

Central Bank of Nigeria (CBN) (2016) Statistical Bulletin, Abuja

Cooray A, (2009). Government expenditure, governance and economic growth. Comparative Economic Studies, 51(3), 401-418.

Ekpo, A. E. \& Umoh, O. J. (2003). An overview of the Nigerian economic growth and development. Retrieved from http://www.onlinenigeria.com/economics/

Fitzgerald, J. \& Leigh, N. G. (2002). Economic revitalization: Cases and strategies for city and suburb. Sage Publications, Incorporated.

Folster, S. \& Henrekson, M. (2001). Growth effects of government expenditure and taxation in rich countries. European Economic Review, 45(8), 1501-1520.

Ranjan K. D. \& Sharma, C. (2008). Government expenditure and economic growth: 
Suleiman, A, \& Aruwa, S. (2009). Public finances and economic growth in Nigeria:

What is Public Expenditure? Meaning and classification. Retrieved from http://kalyan-

city.blogspot.com.ng/2011/02/what-is-public-expenditure-meaning-and.html. 